\title{
Olaparib treatment in older patients with ovarian cancer: need for 'real-world' data beyond clinical trials
}

\author{
Gabor Liposits $^{1 a}$ (D) , Christian Nielsen Wulff ${ }^{2}$, Anne Otland $^{1}$ and Lars Ulrik Fokdal ${ }^{2}$ \\ ${ }^{1}$ Department of Oncology, Region Hospital West Jutland, Gl. Landevej 61, Herning 7400, Denmark \\ ${ }^{2}$ Department of Oncology, Aarhus University Hospital, Palle Juul-Jensens Boulevard 99, Indgang D3, Plan 2, Krydspunkt D203, 8200 Aarhus N, Denmark \\ ahttps://orcid.org/0000-0002-8204-3949
}

\section{Abstract}

Background: Ageing is a risk factor for cancer. Worldwide, the number and proportion of adults aged $\geq 65$ will increase, along with the incidence of ovarian cancer. Older adults are under-represented in randomised clinical trials (RCTs), and those who are enrolled have a good performance status and no major health issues. These patients are not representative of older patients seen in everyday clinical practice; therefore, age-specific data on efficacy and toxicity of olaparib in the 'real-world' setting are lacking.

Methods: This observational study was conducted in the Central Jutland Region in Denmark. Data in unselected older $(\geq 65)$ patients with known BRCA mutation receiving olaparib maintenance treatment for platinum-sensitive relapsed ovarian cancer were registered between 2015 and 2019. Toxicity and progression-free survival (PFS) were registered. No geriatric assessment has been performed.

Results: In total, 20 consecutive patients $\geq 65$ years were included with a median age of 75 years (range: $65-85)$. Most of the patients (18/20) had ECOG PS: 0-1. Treatment interruption and dose reduction occurred in $65 \%$ of the patients. Toxicities of any grade occurred in 18 (90\%), whereas grade $3 / 4$ toxicities occurred in 6 patients (30\%). Treatment was terminated due to disease progression or unacceptable toxicity in 13 (65\%) patients. The median PFS was 6 months (range: 2-31), and the median follow-up was 15 months (range: 3-30).

Discussion: Our 'real-world' experience shows that unselected older patients represent a significant larger proportion in real life than in RCTs; furthermore, older patients in a real-world setting may experience more side effects possibly affecting the quality of life. The median PFS data suggest that older patients may not derive the same clinical benefit than their fit and younger counterparts.

There is a need to enrol vulnerable/frail older patients into RCTs, ensuring that data will also be applicable in standard clinical settings. Incorporating geriatric assessment into these trials should be encouraged.

Keywords: olaparib, older patients, geriatric assessment, ovarian cancer, real-world data, quality of life

Correspondence to: Gabor Liposits

Email: gabor.liposits@rm.dk

ecancer 2020, 14:1104

https://doi.org/10.3332/ecancer.2020.1104

Published: $15 / 09 / 2020$

Received: 31/01/2020

Publication costs for this article were supported by ecancer (UK Charity number 1176307).

Copyright: (c) the authors; licensee ecancermedicalscience. This is an Open Access article distributed under the terms of the Creative Commons Attribution License (http:// creativecommons.org/licenses/by/3.0), which permits unrestricted use, distribution, and reproduction in any medium, provided the original work is properly cited. 


\section{Background}

Ageing is a risk factor for cancer [1]. Due to the ageing of the population, the percentage of the European population aged over 65 years is projected to increase from $17.1 \%$ in 2008 to $30.0 \%$ in 2060 [2]. In parallel with the demographic shift of the population, the incidence of ovarian cancer is expected to rise [3, 4].

In 2012, a total of 565 patients were diagnosed with ovarian cancer in Denmark, and $41.9 \%$ were 70 years or older. The incidence rates among older patients were three times, and the mortality rates were 3-4 times higher than in patients aged $<70$. Well known that the outcomes in older women with ovarian cancer are worse, and the probability of receiving standard treatment, in accordance with guidelines, is reduced by $50 \%[6,7]$.

The randomised controlled trials (RCTs) are the gold standard guiding the management of patients with cancer. Older adults are frequently under-represented in RCTs [6-10], and those who are enrolled are typically in good performance status (ECOG 0-1) and have adequate organ functions [11]. A pooled analysis of eight prospective phase I/II trials [11] including patients $(n=398)$ with recurrent ovarian cancer who received olaparib capsules showed that $19.6 \%(n=78)$ of patients were 65 , and only $10 \%(n=40)$ were 70 years or older. All patients received the maximum tolerable dose of olaparib (400 mg bid), suggesting that these patients were fit and had no significantly impaired organ functions. In general, these fit older patients do not represent the majority of older patients seen in everyday clinical practice, who are often vulnerable and have comorbidities (Figure 1) [6].

A currently published review by the Young International Society of Geriatric Oncology [12] concluded that age-specific data in older patients with ovarian cancer, treated with poly ADP-ribose polymerase inhibitor (PARPi), are lacking. Hence, sparse available evidence suggests that fit older patients with ovarian cancer may benefit from PARP inhibitors in the maintenance setting [13-17]. The health-related quality-of-life (HRQoL) data regarding older patients with ovarian cancer treated with olaparib are completely lacking.

\section{Methods}

This observational study was conducted in the Central Region of Jutland, Denmark, in the two departments of oncology which treat patients with ovarian cancer (Department of Oncology, Regional Hospital West Jutland, and Department of Oncology, Aarhus University Hospital). 'Real-world' data in unselected older $(\geq 65)$ patients with known BRCA mutation (germline and/or somatic) receiving PARPi maintenance treatment for platinum-sensitive relapsed ovarian cancer starting treatment between 2015 and 2019 were retrospectively collected. The maintenance of PARPi treatment was given in the form of olaparib capsules, starting dose 400 mg twice daily in 4-week cycles either until progression or unacceptable toxicity. Toxicity and progression-free survival were registered. No comprehensive geriatric assessment has been performed; however, some patients received geriatric screening.

\section{Results}

In total, 20 consecutive patients (Table 1 ) aged $\geq 65$ years were included with a median age of 75 years (range: 65-85). All patients received at least one previous line platinum-containing chemotherapy for relapsed disease. Eighteen patients had ECOG PS: 0-1, whereas two patients had ECOG PS: 2. Treatment was terminated due to disease progression or unacceptable toxicity in 13 (65\%) patients. The median progression-free survival (mPFS) was 6 months (range: 2-31), and the median follow-up was 15 months (3-30). Treatment interruption and dose reduction occurred in 13 patients (65\%). Toxicities of any grade (Table 1) occurred in 18 patients (90\%). Most common side effects were fatigue (70\%), nausea/vomiting (60\%) and anaemia (20\%). Grade 3/4 toxicities occurred in 6 patients (30\%), and anaemia, infection, nausea/ vomiting, fatigue and neutropenic fever were registered, respectively. Two patients experienced a significant deterioration in physical function and mental well-being due to recurrent infections, fatigue and depression, respectively. After olaparib treatment was stopped, improvement in physical function and mental well-being was observed. 
Table 1. Detailed patient characteristics and treatment outcomes.

\begin{tabular}{|c|c|c|c|c|c|c|c|c|c|}
\hline Patient & Age & ECOG PS \& Comorbidity & $\begin{array}{l}\text { Number of } \\
\text { previous } \\
\text { lines of } \\
\text { platinum for } \\
\text { recurrent } \\
\text { disease }\end{array}$ & $\begin{array}{l}\text { Response } \\
\text { to last } \\
\text { line } \\
\text { platinum } \\
\text { (Imaging } \\
\text { and/or } \\
\text { CA125) }\end{array}$ & $\begin{array}{c}\text { Number } \\
\text { of olaparib } \\
\text { cycles \& best } \\
\text { response } \\
\text { (Imaging and/ } \\
\text { or CA125) }\end{array}$ & $\begin{array}{l}\text { Grade } 3-4 \\
\text { toxicities }\end{array}$ & Grade 1-2 toxicities & $\begin{array}{c}\text { Reason for } \\
\text { discontinuation }\end{array}$ & $\begin{array}{l}\text { Dose } \\
\text { level }\end{array}$ \\
\hline 1 & 67 & 1-none & 6 & PR & $\begin{array}{l}\text { 0-permanent } \\
\text { discontinu- } \\
\text { ation due to } \\
\text { allergic reac- } \\
\text { tion }\end{array}$ & none & $\begin{array}{l}\text { Gr. } 2 \text { urticaria due } \\
\text { allergic reaction }\end{array}$ & Toxicity & 0 \\
\hline 2 & 68 & $\begin{array}{l}\text { 1-Asthma, atrial fibril- } \\
\text { lation, short bowel-syn- } \\
\text { drome }\end{array}$ & 1 & PR & $2-P D$ & none & none & $\begin{array}{l}\text { Progressive } \\
\text { disease }\end{array}$ & 0 \\
\hline 3 & 85 & $\begin{array}{l}\text { 0-asthma, arthrosis, } \\
\text { dyspepsia }\end{array}$ & 1 & PR & $2-S D$ & Gr. 3 nausea & $\begin{array}{l}\text { Gr. } 2 \text { fatigue, } \\
\text { gr. } 2 \text { depression }\end{array}$ & Toxicity & -2 \\
\hline 4 & 65 & 1-none & 1 & PR & $3-S D$ & Gr. 3 anemia & $\begin{array}{l}\text { Gr. } 2 \text { nausea, } \\
\text { gr. } 2 \text { dizziness }\end{array}$ & Toxicity & -1 \\
\hline 5 & 77 & $\begin{array}{l}\text { 0-Atrial fibrillation, dys- } \\
\text { lipidemia, angina pectoris, } \\
\text { arthrosis }\end{array}$ & 1 & PR & $3-S D$ & Gr. 3 infection & $\begin{array}{l}\text { Gr. } 2 \text { fatigue, } \\
\text { gr. } 1 \text { anemia }\end{array}$ & Toxicity & 0 \\
\hline 6 & 79 & $\begin{array}{l}\text { 1-surgery and adju- } \\
\text { vant chemotherapy for } \\
\text { colorectal cancer (2013), } \\
\text { deep venous thrombosis } \\
\text { and lung embolism }\end{array}$ & 1 & PR & $3-S D$ & Gr. 3 fatigue & $\begin{array}{l}\text { Gr. } 2 \text { nausea, } \\
\text { gr. } 2 \text { diarrhea, } \\
\text { gr. } 2 \text { weight loss, gr. } \\
2 \text { anemia }\end{array}$ & Toxicity & -2 \\
\hline 7 & 66 & 1-Asthma & 1 & PR & 4-PD & none & $\begin{array}{l}\text { Gr. } 2 \text { nausea, } \\
\text { gr. } 1 \text { fatigue, } \\
\text { gr. } 1 \text { neutropenia }\end{array}$ & $\begin{array}{l}\text { Progressive } \\
\text { disease }\end{array}$ & -2 \\
\hline 8 & 75 & 1-none & 2 & PR & 4-PD & none & Gr. 1 fatigue & $\begin{array}{l}\text { Progressive } \\
\text { disease }\end{array}$ & 0 \\
\hline 9 & 77 & 1-none & 1 & PR & 4-PD & $\begin{array}{l}\text { Gr. } 3 \text { febrile } \\
\text { neutropenia }\end{array}$ & none & $\begin{array}{l}\text { Progressive } \\
\text { disease }\end{array}$ & -1 \\
\hline 10 & 66 & $\begin{array}{l}\text { 2-heart failure, hypothy- } \\
\text { reosis }\end{array}$ & 1 & PR & 6-SD & none & $\begin{array}{l}\text { Gr. nausea, } \\
\text { gr. } 1 \text { fatigue }\end{array}$ & $\begin{array}{l}\text { Progressive } \\
\text { disease }\end{array}$ & -2 \\
\hline 11 & 72 & $\begin{array}{l}\text { 2-Chronic obstruc- } \\
\text { tive pulmonary disease, } \\
\text { osteoporosis, sarcopenia, } \\
\text { hypertension, depression, } \\
\text { early breast cancer-re- } \\
\text { ceived adj. chemotherapy, } \\
\text { radiotherapy, aromatase } \\
\text { inhibitor and trastuzumab } \\
\text { (2016). }\end{array}$ & 1 & PR & 7-SD & none & $\begin{array}{l}\text { Gr. } 2 \text { nausea, } \\
\text { gr. } 1 \text { fatigue }\end{array}$ & $\begin{array}{l}\text { Progressive } \\
\text { disease }\end{array}$ & -2 \\
\hline
\end{tabular}


Table 1. Detailed patient characteristics and treatment outcomes. (Continued)

\begin{tabular}{|c|c|c|c|c|c|c|c|c|c|}
\hline 12 & 70 & 0-none & 1 & PR & $8-S D$ & none & $\begin{array}{l}\text { Gr. } 1 \text { fatigue, } \\
\text { gr. } 1 \text { myalgia, } \\
\text { gr. } 1 \text { abdominal pain }\end{array}$ & $\begin{array}{l}\text { Progressive } \\
\text { disease }\end{array}$ & 0 \\
\hline 13 & 73 & $\begin{array}{l}\text { 0-dyslipidemia, osteo- } \\
\text { porosis }\end{array}$ & 2 & PR & 9-SD & none & $\begin{array}{l}\text { Gr. } 1 \text { fatigue, } \\
\text { gr. } 1 \text { nausea, } \\
\text { gr. } 1 \text { neutropenia }\end{array}$ & Ongoing & -1 \\
\hline 14 & 71 & $\begin{array}{l}\text { 0-osteoporosis, transient } \\
\text { ischemic attack, lung } \\
\text { embolism }\end{array}$ & 4 & PR & $9-S D$ & none & $\begin{array}{l}\text { Gr. } 1 \text { headache, } \\
\text { gr. } 1 \text { fatigue, } \\
\text { gr. } 1 \text { dyspnea } \\
\text { gr. } 1 \text { blurred vision }\end{array}$ & Ongoing & 0 \\
\hline 15 & 67 & 1-breast cancer (2000) & 1 & PR & $12-S D$ & none & $\begin{array}{l}\text { Gr. } 1 \text { abdominal } \\
\text { pain, } \\
\text { gr. } 1 \text { nausea, } \\
\text { gr.1 fatigue }\end{array}$ & Ongoing & 0 \\
\hline 16 & 77 & 1-hypertension & 2 & $\mathrm{CR}$ & $14-S D$ & none & $\begin{array}{l}\text { Gr. } 1 \text { anemia, } \\
\text { gr. } 1 \text { fatigue, } \\
\text { gr. } 1 \text { nausea }\end{array}$ & Ongoing & -2 \\
\hline 17 & 78 & $\begin{array}{l}\text { 1-pulmonary embolism, } \\
\text { lung cancer (St.I) acci- } \\
\text { dental fund-removed by } \\
\text { surgery }\end{array}$ & 2 & CR & $15-S D$ & none & $\begin{array}{l}\text { Gr. } 2 \text { nausea, } \\
\text { gr. } 2 \text { fatigue, } \\
\text { gr. } 1 \text { elevated se- } \\
\text { creatinine }\end{array}$ & Ongoing & -2 \\
\hline 18 & 74 & 0-hypertension & 1 & $\mathrm{CR}$ & $19-S D$ & Gr. 3 anemia & Gr. 1 nausea & Ongoing & -2 \\
\hline 19 & 80 & $\begin{array}{l}\text { 1-early breast cancer } \\
\text { (1991) }\end{array}$ & 1 & $\mathrm{CR}$ & $29-S D$ & none & $\begin{array}{l}\text { Gr. } 1 \text { fatigue, } \\
\text { gr. } 1 \text { diarrhea, } \\
\text { gr. } 1 \text { nausea, } \\
\text { gr. } 1 \text { dizziness, } \\
\text { gr. } 1 \text { alopecia, } \\
\text { gr. } 2 \text { neutropenia }\end{array}$ & $\begin{array}{l}\text { Progressive } \\
\text { disease }\end{array}$ & -2 \\
\hline 20 & 77 & $\begin{array}{l}\text { 1-hypertension, early } \\
\text { breast cancer (2006) }\end{array}$ & 1 & $\mathrm{CR}$ & $31-S D$ & none & $\begin{array}{l}\text { Gr. } 2 \text { nausea, } \\
\text { gr. } 2 \text { fatigue, } \\
\text { gr. } 1 \text { elevated se- } \\
\text { creatinine }\end{array}$ & Ongoing & -2 \\
\hline
\end{tabular}

\section{Discussion}

Although our observations have several limitations, these data should be put in context getting the right interpretation. The number of included patients $(n=20)$ seems modest although, to the best of authors' knowledge, the cohort is the largest cohort of consecutive unselected older patients received olaparib treatment.

In this region, in total, 39 patients received olaparib maintenance treatment, of whom 20 (52\%) were 65 years or older, whereas, in the largest published cohort, which was a pooled analysis of eight trials [11], only $19.8 \%$ suggest that unselected older patients represent a significant larger proportion in real life than in RCTs, because of the selection bias in phase II/III RCTs including exclusively fit older patients.

The toxicity profile of PARPi appears to be acceptable based on available data from RCTs although the occurrence of clinically significant toxicity is likely to be higher in 'real-world' settings. The data show that older patients in real-world setting experience more side effects possibly affecting HRQoL negatively. A possible explanation could be that high-grade peak toxicity may not reflect the full toxicity burden of PARPi. Chronic low-grade toxicities may be even more important affecting HRQoL for this group of patients [19]. In addition, recently published papers $[18,20]$ elucidated that publications reporting the effectiveness and safety of cancer drugs often use subjective terms that downplay 
the seriousness of adverse events. A representative example is the SOLO2 trial, where olaparib did not improve the prespecified primary quality-of-life analysis, and this was interpreted as 'olaparib is not having a significant detrimental effect on QoL' and 'there were clinically meaningful patient-centred benefits despite the adverse effects' [18].

The mPFS was shorter in this cohort than mPFS data in phase II trial (6.0 versus 11.2 months) based on olaparib received approval, suggesting that older patients may not derive the same clinical benefit than their fit and younger counterparts. Thought provoking that olaparib received accelerated approval based on response rates alone and was required to assess PFS and OS in confirmatory trails. However, olaparib received full approval based on improved PFS alone. At the time of full approval, overall survival data were not yet matured [20]. Given the high cost of treatment with PARPi and the economical strain on the healthcare systems worldwide, it is essential to identify the older patients who are likely to benefit from PARPi. Omitting the treatment of older and vulnerable patients who do not benefit of PARPi treatment means avoidance of toxicities, hospitalisations and less healthcare expenses.

The above-mentioned data suggest that there is a need to enrol vulnerable or frail older patients into RCTs to secure that results from RCTs will also be applicable in a standard clinical setting. In addition, incorporating geriatric assessment into these trials should be encouraged to adequately risk-stratify older patients [21-27] and to help balance the potential benefits and harms of PARPi treatment. The geriatric assessment may guide appropriate patient selection, avoid both over and undertreatment and, thus, may help preserve physical function and mental well-being while reducing the socioeconomic burden of this expensive cancer treatment.

\section{Conclusion}

Older vulnerable patients receiving olaparib in a 'real-world' clinical setting experience more side effects possibly affecting quality of life negatively and have shorter mPFS benefit. RCTs including older unselected patients must ensure that data from RCTs will be applicable in the everyday clinical setting. Geriatric assessment should be an essential component of these trials.

\section{Future perspective}

The working group is planning to start a prospective observational study including older patients with ovarian cancer treated with PARPi, where geriatric assessment-guided patient stratification is a central element, and the study will focus on mPFS, HRQoL and geriatric endpoints.

\section{Conflicts of interest}

None.

\section{Funding statement}

No funding was received for this work.

\section{References}

1. Yancik R (1997) Cancer burden in the aged: an epidemiologic and demographic overview Cancer 80 1273-1283 https://doi.org/10.1002/

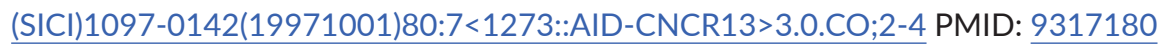

2. Giannakouris K (2008) Population and Social Conditions. Ageing Characterises the Demographic Perspectives of the European Societies (Luxemburg: Eurostat Statistics in Focus) p 72

3. SEER Cancer Statistics Factsheets: Female Breast Cancer (Bethesda: National Cancer Institute.) [https://seer.cancer.gov/statfacts/html/ breast.html] 
4. Smith BD, Smith GL, and Hurria A, et al (2009) Future of cancer incidence in the United States: burdens upon an aging, changing nation J Clin Oncol 27(17) 2758-2765 https://doi.org/10.1200/JCO.2008.20.8983 PMID: 19403886

5. Ør Knudsen A, Schledermann D, and Nyvang GB, et al (2016) Trends in gynecologic cancer among elderly women in Denmark, 19802012 Acta Oncol 55(Suppl 1) 65-73 Epub 2016 Jan 19 https://doi.org/10.3109/0284186X.2015.1115119

6. Dumas L, Ring A, and Butler J, et al (2016) Improving outcomes for older women with gynaecological malignancies Cancer Treat Rev 50 99-108 https://doi.org/10.1016/j.ctrv.2016.08.007 PMID: 27664393 PMCID: 5821169

7. Fourcadier E, Trétarre B, and Gras-Aygon C, et al (2015) Under-treatment of elderly patients with ovarian cancer: a population-based study BMC Cancer 15937 https://doi.org/10.1186/s12885-015-1947-9

8. Scher KS and Hurria A (2012) Under-representation of older adults in cancer registration trials: known problem, little progress J Clin Oncol 30(17) 2036-2038 https://doi.org/10.1200/JCO.2012.41.6727 PMID: 22547597

9. Singh H, Kanapuru B, and Smith C, et al (2017) FDA analysis of enrollment of older adults in clinical trials for cancer drug registration: a 10-year experience by the U.S. Food and Drug Administration J Clin Oncol 35(15_suppl) 10009 https://doi.org/10.1200/ JCO.2017.35.15_suppl.10009

10. Hamaker ME, Stauder R, and van Munster BC (2014) Exclusion of older patients from ongoing clinical trials for hematological malignancies: an evaluation of the National Institutes of Health Clinical Trial Registry Oncologist 19(10) 1069-1075 https://doi.org/10.1634/ theoncologist.2014-0093 PMID: 25170014 PMCID: 4201007

11. Dockery LE, Tew WP, and Ding K, et al (2017) Tolerance and toxicity of the PARP inhibitor olaparib in older women with epithelial ovarian cancer Gynecol Oncol 147(3) 509-513 https://doi.org/10.1016/j.ygyno.2017.10.007 PMID: 29037805

12. Liposits G, Loh KP, and Soto-Perez-de-Celis E, et al (2018) PARP inhibitors in older patients with ovarian and breast cancer: Young International Society of Geriatric Oncology review paper J Geriatr Oncol pii: S1879-4068(18)30314-X https://doi.org/10.1016/j. jgo.2018.10.008 PMID: 30333088

13. Ledermann J, Harter P, and Gourley C, et al (2012) Olaparib maintenance therapy in platinum-sensitive relapsed ovarian cancer N Engl J Med 366(15) 1382-1392 https://doi.org/10.1056/NEJMoa1105535 PMID: 22452356

14. Ledermann JA, Harter P, and Gourley C, et al (2016) Overall survival in patients with platinum-sensitive recurrent serous ovarian cancer receiving olaparib maintenance monotherapy: an updated analysis from a randomised, placebo-controlled, double-blind, phase 2 trial Lancet Oncol 17(11) 1579-1589 https://doi.org/10.1016/S1470-2045(16)30376-X PMID: 27617661

15. Ledermann JA, Harter P, and Gourley C, et al (2016) Quality of life during olaparib maintenance therapy in platinum-sensitive relapsed serous ovarian cancer Br J Cancer 115(11) 1313-1320 https://doi.org/10.1038/bjc.2016.348 PMID: 27824811 PMCID: 5129820

16. Pujade-Lauraine E, Ledermann JA, and Selle F, et al (2017) Olaparibtablets as maintenance therapy in patients with platinum-sensitive, relapsed ovarian cancer and a BRCA1/2 mutation (SOLO2/ENGOT-Ov21): a double-blind, randomised, placebo-controlled, phase 3 trial Lancet Oncol 18(9) 1274-1284 https://doi.org/10.1016/S1470-2045(17)30469-2 PMID: 28754483

17. Friedlander M, Gebski V, and Gibbs E, et al (2018) Health-related quality of life and patient-centred outcomes with olaparib maintenance after chemotherapy in patients with platinum-sensitive, relapsed ovarian cancer and a BRCA1/2 mutation (SOLO2/ENGOT Ov-21): a placebo-controlled, phase 3 randomised trial Lancet Oncol 19(8) 1126-1134 https://doi.org/10.1016/S1470-2045(18)30343-7 PMID: 30026002

18. Gyawali B, Shimokata T, and Honda K, et al (2018) Reporting harms more transparently in trials of cancer drugs BMJ $363 \mathrm{k} 4383$ https:// doi.org/10.1136/bmj.k4383 PMID: 30385466

19. D Lorusso and Pignata S (2018) PARPi related toxicities: do we need more appropriate instruments to evaluate it? Ann Oncol 29(8) 1613-1616 https://doi.org/10.1093/annonc/mdy189 PMID: 29790901 
20. Gyawali B, Hey SP, and Kesselheim AS (2019) Assessment of the clinical benefit of cancer drugs receiving accelerated approval JAMA Intern Med 179(7) 906-913 https://doi.org/10.1001/jamainternmed.2019.0462 PMID: 31135808 PMCID: 6547118

21. Soto-Perez-de-Celis E, Li D, and Yuan Y, et al (2018) Functional versus chronological age: geriatric assessments to guide decision making in older patients with cancer Lancet Oncol 19 e305-e316 https://doi.org/10.1016/S1470-2045(18)30348-6 PMID: 29893262

22. Loh KP, Soto-Perez-de-Celis E, and Hsu T, et al (2018) What every oncologist should know about geriatric assessment for older patients with cancer: Young International Society of Geriatric Oncology Position Paper J Oncol Pract 14 85-94 https://doi.org/10.1200/ JOP.2017.026435 PMID: 29436306 PMCID: 5812308

23. Jolly TA, Deal AM, and Nyrop KA, et al (2015) Geriatric assessment-identified deficits in older cancer patients with normal performance status Oncologist 20 379-385 https://doi.org/10.1634/theoncologist.2014-0247 PMID: 25765876 PMCID: 4391761

24. Hamaker ME, Vos AG, and Smorenburg CH, et al (2012) The value of geriatric assessments in predicting treatment tolerance and all-cause mortality in older patients with cancer Oncologist 17 1439-1449 https://doi.org/10.1634/theoncologist.2012-0186 PMID: 22941970 PMCID: 3500366

25. Hurria A, Mohile S, and Gajra A, et al (2016) Validation of a prediction tool for chemotherapy toxicity in older adults with cancer J Clin Oncol 34 2366-2371 https://doi.org/10.1200/JCO.2015.65.4327 PMID: 27185838 PMCID: 5321104

26. Mohile SG, Dale W, and Somerfield MR, et al (2018) Practical assessment and management of vulnerabilities in older patients receiving chemotherapy: ASCO guideline for geriatric oncology J Clin Oncol 36 2326-2347 https://doi.org/10.1200/JCO.2018.78.8687 PMID: 29782209 PMCID: 6063790

27. Wildiers H, Heeren P, and Puts M, et al (2014) International Society of Geriatric Oncology consensus on geriatric assessment in older patients with cancer J Clin Oncol 32 2595-2603 https://doi.org/10.1200/JCO.2013.54.8347 PMID: 25071125 PMCID: 4876338 